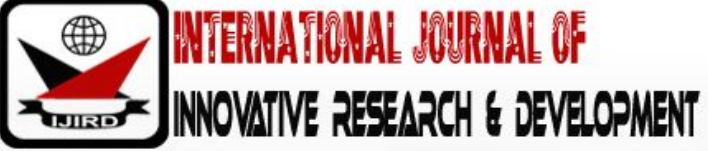

ISSN 2278 - 0211 (Online)

\section{Challenges of Implementing Integrated Social Studies Curriculum in Basic Schools: A Study of Cape Coast Metropolis}

\author{
Angbing Hippolyt Dickson \\ Senior Lecturer, Department of Basic Education, University of Cape Coast, Ghana \\ Rebecca Esi Ampofo \\ Teacher, Department of Arts and Social Sciences, Foso College of Education, Ghana
}

\begin{abstract}
:
This study is a follow up or confirmatory study of an earlier study that dealt with tutors of Colleges of Education perceptions about integrating social studies teaching with science in the three Colleges of Education in the Central Region. The current study sought the possibility of uncovering the hindrances social studies teachers at the basic school level encounter in implementing integrated curriculum of social studies. The main purpose of the study was to explore the strategies for integrated study of any kind as well as the difficulties educators in basic schools in Ghana face in using integrated curriculum approach in teaching social studies. The study employed the descriptive survey. The targeted population for the study was all Social Studies teachers in the basic schools in the Cape Coast Metropolis in the Central Region. The researchers used simple random sampling technique to select 30 Social Studies teachers from 30 basic schools within Cape Coast Metropolis. Questionnaire was the main instrument used for data collection and the result from the study indicated that there are factors hindering teachers use of integration in Basic Schools in the study area. The study recommended that for effective use of integrated curriculum at the basic school level, Pre service teachers should be made to fully appreciate the concept of integrated curriculum and how to make effective use of the approach in teaching. Again, the difficulties or hindrances of teachers use of integrated approach in teaching social studies can be minimized if there are post qualification professional development workshops to keep teachers updated on how to teach across disciplines while maintaining social studies as an independent subject.
\end{abstract}

Keywords: Challenges, integration, social studies, basic school, teacher

\section{Introduction}

Social Studies is a single composite instructional area which draws its contents from many of the Social Sciences and humanities. Social Studies does not combine Social Science subjects in unrelated way rather it integrates them for the purpose of helping the learners understand human relationship with the society/ environment in which they live. Developing the competencies relating to healthy social living is the main aim of Social Studies learning. Social Studies is concerned with the practical aspects of the society. From the very early start of Social studies, it was built on the foundations of history which was recognized as the central study of Social Studies in Britain and later in the United States of America in 1916. The change from the traditional subjects of history to Social Studies occurred in the Jones Report (Ravitch \& Viterittis, 2003) on social studies; incorporated into the famous Cardinal Principle Report of the National Education Association in 1918 which suggested that the goal of Social Studies was good citizenship and that historical studies that did not contribute to social change had no value. This report gave a strong boost to Social Studies teaching. The study of History was considered too-academic and far removed from students' immediate needs and that they made no contributions to social efficiency. It was in the field of social efficiency that Social Studies were born.

The terms curriculum integration and interdisciplinary integration is generally used interchangeably in the related literature (Toren, 2008, cited in Sahinkaya \& Aladag 2009). Interdisciplinary curriculum can be defined as "a curriculum approach that consciously applies methodology and language from more than one discipline to examine a central theme, issue, problem, topic or experience" (Jacobs, 1989 cited in Sahinkaya \& Aladag 2009). Curriculum integration helps learning some subjects. Although integration is not necessary, it is often desirable. The content learned from one subject is used to teach another (Brophy and Alleman,2002 Sahinkaya\&Aladag2009)

\subsection{Statement of the Problem}

Social studies are one of the core subjects taught at the basic and second cycle level of education in Ghana. Social studies are considered a key subject because of its perceived importance in instilling its learner with civic responsivities and competent individuals who can help solve personal, national and environmental issues where ever they are found. The spirit behind the teaching of social studies is to see the world as one whole and therefore avoid compartmentalization of knowledge into subject areas. It is argued that children do not view the world as fragmented but as a whole. Therefore, 
teaching social studies in the basic school level and indeed at all levels should be taught as an integrated subject whereby teachers will help learners tease out the relationship that exists among various disciplines making up social studies rather than teaching disciplines that make up social studies as separate disciplines. It has however been noticed that, most teachers across different levels of education in Ghana still teach social studies as separate academic disciplines. This study is therefore an attempt to find out the challenge's teachers face in teaching social studies using the concept of integration due to subject specialty.

Restructuring of the country's educational curriculum to be integrated and designed in a way that would focus on problems and issues that are connected with real situation as well as providing continued support and professional development opportunities for teachers would be the catalyst to help future educators understand the craft of integration and this would go a long way to curtail the problem of neglect, exemption and restriction of some students from core discipline for academic progression (Koch, 2014). Teaching has become increasingly more complex, because of the considerable amount of educational restructuring; numerous innovations have surfaced including integrated curriculum. As educators, we are mandated to constantly search for new ways to help students make sense of the multitude of life's experience and the bits and pieces of knowledge they gain from traditional compartmentalized curriculum. Learners today continue to move from one discipline to the next forcing the information to be disconnected to anything that resembles real life situations. To lighten some of the fragmentation in the knowledge to be acquired by learners, and experience to be gained by teachers, holistic and integrated curriculums are being proposed and adopted by many school districts in the U.S which is a major driving force behind integrated teaching and learning. It is the belief that when themes, subjects, or projects are combined, students begin to see meaningful connections between the different disciplines (Vars, 1991). Kain (1993) found out that many students felt that integrated curricula were more relevant to the real world, due to real world problems of the interdisciplinary nature, and this increased both their learning and motivation. The argument is that integrated approach would present related concepts from geography, Government, Historyin holistic form rather than a single subject perception. Thus, the problem of restriction and exemption of some students from the study of specific disciplines can be best tackled by the integrated approach of teaching. Several studies have been done for instance, Sahinkaya and Aladag (2009) studied on the integration between mathematics and social studies by the examining the activities in the social studies program and elsewhere with respect to integration of Social Studies with other subjects; McBrien and R. S. Brandt, (1997. Teachers who participated in integrated curriculum submitted that they become more effective in teaching as a result of their participation (Johnson et al, 2003). However, it appears there no studies within the Ghanaian context that justifies the need for a study that focuses on the challenges of integrated curriculum of Social Studies in basic schools.

\subsection{Purpose of the Study}

The purpose of the study was to afford the researchers make a comparison between the hindrance teachers face teaching social studies as an integrated subject in the basic schools against tutors of Colleges of Education. In an earlier study, the researchers sought to find out the relationship that exist between social studies tutors and science tutors' perception of curriculum integration of science and social studies. The study concluded that, there was a strong positive relationship between the two groups of tutors' perceptionson the idea of curriculum integration. This study was therefore meant to confirm or challenge the earlier findings by undertaking the study at the basic school level. This was done on purpose. The products of the Colleges of Education teach at the basic school level. The outcome of the study was meant to deepen the idea of integration as a concept especially on the teaching of social studies across all levels of education in Ghana,

\subsection{Research Questions}

The following questions guided the study:

- What strategies account for the integration of Social Studies with the teaching of Science?

- What are the factors hindering tutors' use of integration in the Colleges of Education?

\section{Literature Review}

Integratedlearningreferstoeducationthatisorganizedinsuchawaythatit cuts across subject-matter lines, bringing together various aspects of the curriculum into meaningful association to focus upon broad areas of the study. It views learning and teaching in holistic way and reflects the real world, which is interactive (Shoemaker, 1989, p. 5).

Jacob on the other hand also defines integrated or interdisciplinary as 'a knowledge view and curricular approach that consciously applies methodology and language from more than one discipline to examine a central theme, issue problem, topic, or experience' (1989, p. 8). To Beane (1997) saw integration as a way to teach students that attempts to break down the barriers between subjects and make learning more meaningful to students. The idea is to teach around themes or organizing centers 'that students can identify with, such as the 'The Environment', Iife in school', or more traditional areas like 'Myths and Legends' (p. 13-14).

In general, all the definitions of integrated curriculum or integrated teaching include the following:

- A combination of subjects: more than one curricular subject areas are combined to evolve a natural continuum of contents and activities which is related to the earlier experiences and related to the real-life issues of the learner.

- Sources that go beyond textbooks: since the integrated material relate to the direct and real-world experiences of the learners, the transaction goes beyond the contrived, abstract and unfamiliar textbook materials.

- Relationships among concepts: the concepts selected from different subjects for preparing an integrated lesson are interrelated with each other so as to constitute a meaningful whole for the learner. Holistic meaning is more 
important than fragmented unrelated concepts which carry very little learning for the learners.

- Thematic units as organizing principles: the integration of the related concepts is invariably around a home familiar to the learnerslike 'water', 'Energy', 'Environment' and Election (McConney\&Maor,

- 2009, p. 34).

- An emphasis on projects: a project relates to a social issue concerning the learner which is carried to completion in its natural setting. In order to complete a project, the learners, preferably work in groups, are required to combine all their knowledge and experience relating to different disciplines in order to solve a real-lifeproblem.

- Flexible schedules: the integrated teaching-learning cannot be confined to any fixed period within the classroom time table. Enough of freedom has to be given both in terms of time and space for effective transaction of integration of concepts.

- Flexible student groupings: in order that the integrated learning to be meaningful and effective for the learners, flexibility in grouping, preferably heterogeneous grouping with student's interest and choice, need to be adopted. Heterogeneous grouping helps in Curriculum integration requires a shift in the traditional role of the teacher. It is more dynamic, interactive and finely nuanced than teaching a thematic unit. It requires teachers to share decision making and the messy process of inquiry, where the outcomes are unknown. As such it can feel both demanding and daunting for those who are new to it.

It can be noticed from the above dictates of what integration entails, that teachers have genuine difficulties in implementing the social studies curriculum in an integrated manner. The pre-service training usually given to teachers at the Colleges of Education and universities with bias in teacher preparation in Ghana, prepare students in separate subject areas although it is usually referred to as social studies. The issue of tutors teaching in subject areas and yet call it social studies has its origins in the start of social studies as academic subject area when it was first introduced in Ghana in the early 1940's. The originators of the idea of integration were themselves specialist in various subject areas such as History, Geography, Economics among others. These teachers had no formal training in team teaching, Again, each tutor saw himself/ herself as a specialist in particular subject area and therefore did not want to' surrender' the 'sovereignty' of their individual subject areas. If this were to be done in their estimation, their individual subject identities will be lost together with their perceived dignity as specialist in their own right. As teachers were not willing to give up their individual subject orientations by teaching social studies as an integrated subject this has since been a challenge in teaching social studies as an integrated subject at least in Ghana. This early resistance to integration has impacted negatively on the products of the colleges of education and universities who are expected to teach social studies bearing in mind its integrated nature. It is therefore not uncommon to observe a teacher teaching social studies in the basic school indicate the subject on the board as social studies and put into brackets (History, geography etc.)

Etim (2005), comments on teachers' feelings of exhaustion when trying curriculum integration because they are required to take on roles different from their usual ways of operating. Some teachers may feel threatened by its approach for a number of reasons, including their reluctance to share decision making and their preference for having activities carefully planned well ahead of time (Etim, 2005).

A further challenge that is known to cause concern is teachers' lack of knowledge about curriculum integration. When not done well, curriculum integration can become as forced or artificial as any poorly executed approach, resulting in lack of student motivation and engagement (Beane, 2005). Another impediment for some is the concern that they will not be covering what the curriculum requires. Teachers do need to remember the big picture and ensure their Social Studies or Science programme, for instance, is not overlooked just because Social Studies or Science does not feature in an integrated unit. There is place and space for stand-alone subject teaching alongside any integrated unit. The erroneous belief that curriculum integration incorporates all learning areas leads some to raise this concern. Curriculum integration only draws on those learning areas germane to the inquiry at hand.

Finally, time is one of the biggest factors in the successful implementation of curriculum integration, and some believe that curriculum integration requires more time than what is readily available in the classroom schedule (Harrel, 2010). Time however, is a perennial challenge in any approach to teaching and it should not be used as an excuse not to innovate. Anecdotal evidence suggests that teachers save time. In the long run because they are not caught up in the minutiae of narrow planning, teaching and assessing, but are instead liberated to facilitate students' inquiry into deep and compelling issues. Instead of curriculum coverage, the emphasis is on depth of learning.

Constructivism as paradigm or worldview posits that learning is an active, constructive process. The learner is an information constructor. People actively construct or create their own subjective representations of objective reality. New information is linked to prior knowledge, thus mental representations are subjective. According to constructivist theory, adult learners, much like children, construct knowledge structures in their mind in a nonlinear fashion. The constructivist learning theory was used to organize and guide the research. The constructivist theory supports integrated contextual learning. That is, individuals do not learn based on isolated facts; instead, individuals learn in relationship to what is already known (Richardson, 2003). The theory of constructivism also recognizes that learning is a social activity, and that interactions with peers are an integral element of learning (Ackermann \& Mitsakos, 2001; Richardson, 2003). Through opportunities for hands- on explorations, learners develop conceptual understandings. Knowledge is created through interactions with the world, people, and things (Ackermann \& Mitsakos, 2001; Fosnot \& Perry, 2006). Put in another way, knowledge is actively constructed and constructed through personal experiences (Ackermann \& Mitsakos, 2001; Hein, 1991; Richardson, 2003). Constructivist learning theory says that all knowledge is constructed from a base of prior knowledge. Children are not a blank slate and knowledge cannot be imparted without the child making sense of it according his or her current conceptions.

Instead of providing answers to questions, instructors in a constructivist model facilitate the learning process to 
enable students to build personal knowledge. Constructivist theory is characterized by a student- centered approach to learning and an engagement in dialogue, which leads knowledge creation about a topic. If necessary, direct instruction is offered. Direct instruction is strategy in which the teacher and or researcher guide the participants in how to participate in effective orientation and activities learning to help them become comfortable with the constructivist process. In contemporary times, constructivist learning can involve reference to informational texts, exploring websites, and structured opportunities for Students' to challenge change, or add to previous knowledge and develop their critical thinking (Richardson, 2003).

Based on the constructivist theory, as participants collaborate, they learn through connections with new information from prior knowledge. As they plan, implement, and evaluate, they learn through the process of inquiry (Becker, Mentzer, Huang \& Park, 2012). Constructivism focuses on activities, processes, and social interaction among children and adults. To enhance the thinking phase, participants need to engage in collaborative professional development. Teachers who share the same practices, ideas, and language increase their knowledge (Ravitch, 2016; Rebore, 2015). Constructivist theorists indicate that learning is an active process that requires changes in mindset (Danielson, 2007; Richle, 2012). Constructivists do not follow a traditional curriculum. Participants in the study will be engaged in active discourses as they plan and evaluate the intervention it also encourages teachers to avoid in working in isolation.

\section{Methodology}

The study employed the descriptive survey. The targeted population for the study was all Social Studies teachers in the basic schools in the Cape Coast Metropolis in the Central Region. The researchers used simple random sampling technique to select 30 Social Studies teachers from 30 basic schools within six educational circuits in Cape Coast Metropolis. Questionnaire was the main instrument used for data collection. The instrument was pilot tested in the Komenda Edina Eguafo Abrem Municipality of the Central Region the purpose of the pilot testing was to find out 'sharpness' suitability and adequacy of the instruments. A few corrections were affected before the administration of the instrument.

\section{Results and Discussion}

\subsection{Research Question One: What Strategies Account for Integration of Social Studies in Basic Schools?}

The purpose of this research question was to determine the strategies that accounted for integration of Social Studies at the basic school level. Seven statements were used to answer this question. Analysis of results in relation to this question was based on section B, of the questionnaire; items 21 -27. To achieve this, means and standard deviations were used for the analysis. The results are shown on Table1.

\begin{tabular}{|c|c|c|c|c|}
\hline \multirow[t]{2}{*}{ Statements } & \multicolumn{2}{|c|}{$\mathrm{TV}=2.50$} & Skewness & MR \\
\hline & $\mathbf{M}$ & Std.D & & \\
\hline $\begin{array}{l}\text { Active learning as an instructional method that engages } \\
\text { the learner }\end{array}$ & 3.67 & .548 & .020 & $1^{\text {st }}$ \\
\hline $\begin{array}{c}\text { Collaborative learning ensures students work together in } \\
\text { small groups towards a common Goal }\end{array}$ & 3.58 & .522 & .030 & $2^{\text {nd }}$ \\
\hline $\begin{array}{c}\text { Cooperative learning as a structured form of group work } \\
\text { with different students' levels of ability is appropriate for } \\
\text { integrated learning }\end{array}$ & 3.52 & .518 & .000 & $3^{\text {rd }}$ \\
\hline $\begin{array}{c}\text { Inquiry-based learning introduces the problem and } \\
\text { provides the context for learning in an integrated } \\
\text { manner. }\end{array}$ & 3.40 & .813 & -.889 & $4^{\text {th }}$ \\
\hline $\begin{array}{l}\text { Debriefing as conversational sessions that revolve } \\
\text { around sharing and examining of information after } \\
\text { specific event facilitate integrated learning }\end{array}$ & 3.23 & .626 & -.201 & $5^{\text {th }}$ \\
\hline $\begin{array}{c}\text { Experiential learning as learning through individual } \\
\text { direct experience }\end{array}$ & 3.20 & .886 & -.420 & $6^{\text {th }}$ \\
\hline $\begin{array}{l}\text { Guided instruction with cues, prompts and questions } \\
\text { facilitate integrated learning }\end{array}$ & 3.16 & .376 & 1.88 & $7^{\text {th }}$ \\
\hline Mean of Means/ Std. D & 3.39 & .612 & & \\
\hline
\end{tabular}

Table 1: Results on Strategies That Account for Integration of Social Studies at Basic Schools Source: Field Survey, (2020) (N=30)

Key-M=Mean, Std. D, Standard Deviation, TV=Test Value, MR=Mean Rank

Table 1 indicates the results on the strategies that account for integration of Social Studies at the basic school level. The results show that, generally, basic school teachers believe that there are some strategies that account for integration of Social Studies at the basic school level. This was quite evident after the mean of means (3.39) produced from the response of the teachers was greater than the TV of 2.50. However, according to the tutors, some of the strategies were more effective than others.

From Table 1, most of the teachers agreed active learning as an instructional strategy that engages the learner $(\mathrm{M}=3.67>2.50, \mathrm{SD}=548, \mathrm{n}=30)$. The tutors further confirmed that collaborative learning ensures students work together in 
small groups toward a common goal and this is one of the most regarded strategy $(\mathrm{M}=3.58>2.50, \mathrm{SD}=522, \mathrm{n}=30$ ). Cooperative learning as a structured form of group work with different students' levels of ability is appropriate for integrated learning was also not left out as one of the strategies $(\mathrm{M}=3.52>2.50, \mathrm{SD}=.518, \mathrm{n}=30)$.

In a similar way, the teachers shared that inquiry-based learning introduces the problem and provides the context for learning in integrated manner and this is one of the most regarded strategy $(\mathrm{M}=3.40>2.50, \mathrm{SD}=813, \mathrm{n}=30)$. Moreover, the analysis pointed out that debriefing as conversational sessions that revolve around sharing and examining of information after specific event facilitate integrated learning $(M=3.23>2.50, \mathrm{SD}=626, \mathrm{n}=30)$.

Experiential learning as learning through individual direct experience context for learning in integrated manner is one of the strategies $(M=3.20>2.50, \mathrm{SD}=.886, \mathrm{n}=30)$. Finally, the result showed that guided instruction with cues, prompts and questions facilitate integrated learning and this serves as one of the strategies $(\mathrm{M}=3.16>2.50, \mathrm{SD}=375, \mathrm{n}=30)$. Once again, these analyses are in unison with the assertions of Vars (2001) that the main purpose of an integrated curriculum is to have a student-centered curriculum that engages students, improves student learning, and increases student interest. Higher-order thinking skills, cooperative learning, and consideration of other students' values are emphasized.

- Research Question Two: What are the factors that hinder teachers' use of integrated curriculum in the teaching of

Social Studies at the basic school level?

The focus of this research question was to assess the factors that hinder teachers' use of integrated curriculum in the teaching of Social Studies at the basic school level. Ten statements were used to answer this question. Analysis of results in relation to this question was based on section $\mathrm{C}$, of the questionnaire items 28 -37. To accomplish this, Means and Standard Deviations were used for the analysis. The results are presented on Table 2.

\begin{tabular}{|c|c|c|c|c|}
\hline \multirow[t]{2}{*}{ Statement } & \multicolumn{2}{|c|}{$\mathrm{TV}=2.50$} & \multicolumn{2}{|c|}{ Skewness MR } \\
\hline & $\mathbf{M}$ & Std. D & & \\
\hline Lack of competence on the part of tutors in & 3.98 & 348 & .049 & $1^{\text {st }}$ \\
\hline \multicolumn{5}{|l|}{ variety of subjects } \\
\hline Students lack of enthusiasm about scientific & 3.88 & .552 & .069 & $2^{\text {nd }}$ \\
\hline \multicolumn{5}{|l|}{ explanation of phenomena } \\
\hline Nonexistence of textbooks and manuals that & 3.72 & .318 & .092 & $3^{\text {rd }}$ \\
\hline \multicolumn{5}{|l|}{ offer enough ideas for integration } \\
\hline Segregated nature of disciplines in the & 3.70 & .453 & .092 & $4^{\text {th }}$ \\
\hline \multicolumn{5}{|l|}{ Curriculum } \\
\hline Insufficient time allocations for lessons on & 3.63 & .566 & .096 & $5^{\text {th }}$ \\
\hline \multicolumn{5}{|l|}{ the time table } \\
\hline Unwillingness on the part of educators to & 3.50 & .543 & .082 & $6^{\text {th }}$ \\
\hline \multicolumn{5}{|l|}{ integrate subjects } \\
\hline Need for development of the level of & 3.45 & .543 & .055 & $7^{\text {th }}$ \\
\hline \multicolumn{5}{|l|}{ knowledge tutors possess } \\
\hline Need for adoption of authentic assessment & 3.34 & 455 & .089 & $8^{\text {th }}$ \\
\hline \multicolumn{5}{|l|}{ strategies e.g. Portfolios } \\
\hline Increase work load on the part of instructors & 3.16 & .545 & .083 & $9^{\text {th }}$ \\
\hline Unwillingness on the part of educators to & 2.93 & .543 & .094 & $10^{\text {th }}$ \\
\hline integrate subjects & & & & \\
\hline Mean of Means/ Std. D & 3.53 & .486 & & \\
\hline
\end{tabular}

Table 2: Results on Factors That Hinder Teachers' Use of Integrated Curriculum in the

Teaching of Social Studies at Basic Schools

Source: Field Survey, (2020) (N=30)

Key-M=Mean, Std. D, Standard Deviation, TV=Test Value, MR=Mean Rank

Table 2 indicates the results on the factors that might hinder teachers' use of integrated curriculum in the teaching of Social Studies at the basic school level. The results show that, basic school teachers are faced with many challenges that hinder teachers' use of integrated curriculum in the teaching of Social Studies. This was quite clear after the mean of means produced from the responses of the teachers was greater than the TV of 2.50.

The statistic values from Table 2 , showed that lack of competence on the part of teachers in variety of subjects is the first major challenge that hinder teachers' use of integrated curriculum in the teaching of Social Studies( $\mathrm{M}=3.98>2.50$, $\mathrm{SD}=348, \mathrm{n}=30$ ). pupils lack of enthusiasm about scientific explanation of phenomena followed with the second greatest mean value $(\mathrm{M}=3.88>2.50, \mathrm{SD}=.552, \mathrm{n}=30)$.

Nonexistence of textbooks and manuals that offer enough ideas for integration was another major hindrance associated with teachers 'use of integrated curriculum in the teaching of Social Studies ( $M=3.72>2.50, \mathrm{SD}=318, \mathrm{n}=30$ ). Segregated nature of disciplines in the curriculum was another major hindrance associated with the teachers' use of integrated curriculum in the teaching of Social Studies at the basic school level ( $M=3.70>2.50, S D=453, n=30)$.

The teachers pointed out $\mathrm{th}$ a t insufficient time all ocations for lessons on the time table was another major hindrance that is linked with the teachers' use of integrated curriculum in the teaching of social studies at the basic school level $(M=3.63>2.50, S D=.566, n=30)$. The teachers further indicated that unwillingness on the part of educators to integrate subjects lead to a major challenge $(\mathrm{M}=3.50>2.50, \mathrm{SD}=.543, \mathrm{n}=30)$. 
The findings generally agree with a host of earlier studies on constraints teachers face in using or adapting integrated approach in teaching. For instance, Etim (2005), comments on teachers' feelings of exhaustion when trying curriculum integration because they are required to take on roles different from their usual ways of operating. Some teachers may feel threatened by this approach for a number of reasons, including their reluctance to share decision making and their preference for having activities carefully planned well ahead of time. To Beane (2005), a further challenge that is known to cause concern is teachers' lack of knowledge about curriculum integration. When not done well, curriculum integration can become as forced or artificial as any poorly executed approach, resulting in lack of student motivation and engagement (Beane, 2005). To Pring (2006), time is one of the biggest factors in the successful implementation of curriculum integration, and some believe that curriculum integration requires more time than what is readily available in the classroom schedule (Pring, 2006).

\section{Conclusions}

The study outlined that; for effective interdisciplinary study, there must be strategies to drive home the desired outcome. The implication of this statement is that indeed, for integrated study to achieve the desired outcome in learners, implementers (teachers) must be abreast with appropriate child centred strategies. The study also revealed that integrated study of any kind would face a number of challenges. It therefore presupposes that; teacher training is crucial as challenges are best overcome with skills.

Furthermore, it can be concluded that since educators are charged with preparing students to be successful, this study provides curricula transformations to enhance students understanding in an educational setting. This study pursued outcomes that were not measured against a fixed set of criteria.

\section{Recommendations} and practice:

Based on the findings and conclusions drawn from the study, the following recommendations are made for policy

The study indicated that for effective interdisciplinary study of any kind there must be strategies that ought to drive home the desired outcome. And such strategies must endeavour to place the student at the center of the learning process. Ghana Education Service and National Council for Tertiary Education must constantly sharpen teachers' pedagogical skills on strategies that place the student at the center of the learning process.

Results from the study indicated that any integrated curriculum approach to instruction in the basic schools' face challenges such as lack of competence on the part of instructors in a variety of subjects, nonexistence of textbooks and manuals that offer enough ideas on integration. It therefore suggested that the National Council for Curriculum and Assessment (NACA) and The Ghana Education Service always endeavour to give post qualification professional development to all teachers so as to equip all teachers to empower the learners for civic participation

\section{References}

i. Ackerman, A., \& Mitsakos, C. (2009). Teaching social studies as a subversive activity. Social Education, 73(1), 40-42.

ii. Aladag, E. Sahinkaya N. (2009).

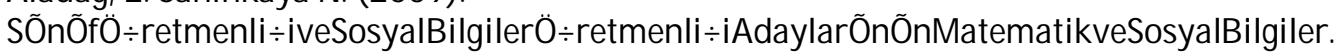

iii. Beane, J. A. (1997). Curriculum integration: Designing the core of democratic education. Teachers College Press.

iv. Beane, J. A. (2005). The middle school: The natural home of integrated curriculum. Educational Leadership, 49(2), 9-13.

v. Danielson, C. (2007). Enhancing professional practice: A framework for teaching (2nd ed.) Alexamdroa. VA: Association for Supervision and Curriculum Development.

vi. Etim, J. S. (Ed.). (2005). Curriculum integration K-12: Theory and practice. U.S.A: University Press of America.

vii. Hein, G. E. \& Price, S. (1991). More than a field trip: Science programmes for elementary school groups at museums. International Journal of Science Education, 13(5), 505-519.

viii. Jacobs, H.H. (1989). The Growing Need for Interdisciplinary Curriculum Content. H.H.] acobs (Ed.), Interdisciplinary curriculum: Design

ix. Kim (2005). The Effects of a Constructivist teaching Approach on student Academic Achievement, Self-Concept, and learning Strategies (PDF) Asia Pacific Education Review 6 (1) 7-19.

x. Maor, D., \& McConney, A (August 1999). Teachers-as-learners: the role of a multimedia professional development program in changing classroom practice. Australian Science Teachers Journal. 45 (3), 45-51.

xi. Mcbrien, J. L. \& Brandt, R. S. (1997). From the Language of Learning: A Guide to Education Terms. Alexandria, VA: ASCD

xii. McConney, A., \& Maor, D. (2009). The Evaluation of a Pilot Mentoring Program for Beginner Science and Mathematics Teachers: Summative Project Evaluation Report. Online submission.

xiii. Murphy, E. (Summer 1979). Constructivism from Philosophy to Practice. Available www: [http:// www.stemnet.nf.ca//

xiv. Parker, W. C., \& Jarolimek, K. (1997). Social studies in elementary education. Columbus: Prentice Hall Inc.

xv. Pring, R. (2006). The philosophy of education. New York: Bloomsbury Publishing.

xvi. Ravitch, D., \& Viteritti, J. P. (Eds.). (2003). making good citizens: Education and civil society. Yale University Press.

xvii. Ravitch, D. (2016). The death and life of the great American school system: how testing and choice are 
undermining education. New York, NY: Basic Books.

xviii. Rebore. R. W. (2015). Human resources administration in education (10thed.). Boston, MA: Pearson Education.

xix. Richardson, V. (2003). Constructivist pedagogy. Teachers College Record, 105(9), 1623-1640.Retrieved from http:/ / kodu.ut.ee/ -triinm/ educational technology2/artikkel4.pdf.

xx. Richle, U. (2012). Interdisciplinary teamw ork: Student differences and teaching implications. American Journal of Health Sciences (AJHS), 1(1), 11-22.

xxi. Schmidt, H. G. \& Loyens, S. M. (2007). Students' conceptions of distinct constructivist assumptions. European Journal of Psychology of Education, 22(2), 179-199.

xxii. Shoemaker, B. J. E. (1989). Integrative Education: A Curriculum for the Twenty-First Century. OSSC Bulletin, 33(2), 2-19.

xxiii. Torenz., Maiselman, D. \& Inbar, S. (2008). Curriculum Integration

xxiv. Vars, G. F. (2004). Can curriculum integration survive in an era of high-stakes testing? Middle School Journal, 33(2),7-17.

xxv. Van Fossen, P. J. (2005). 'Reading and math take so much of the time...'An Overview of Social Studies Instruction in Elementary Classrooms in Indiana. Theory \& Research in Social Education, 33(3), 376-403. 